\title{
Transfusion Related Acute Lung Injury After latrogenic Intrabdominal Bleeding: A Case Report
}

\author{
Iatrojenik Intrabdominal Kanama Sonrası Transfüzyon ile Ilişskili Akut Akciğer \\ Hasarı: Olgu Sunumu
}

Mehmet Asıl' ${ }^{1}$ Ramazan Dertli ${ }^{1}$, Murat Bıyık' , Hüseyin Ataseven' ${ }^{1}$ Hakkı Polat ${ }^{2}$, Ali Demir ${ }^{1}$

\begin{abstract}
Many patients need transfusion of blood products for various reasons. Transfusion-related acute lung injury (TRALI) is an important and potentially fatal complication which is the leading cause of transfusion-related deaths. It is a form of acute non-cardiogenic pulmonary edema. It can be diagnosed according to the National Heart Lung and Blood Institute (NHLBI) Working Group or the Canadian Consensus Conference criteria. Diagnosis requires an acute onset of hypoxemia with a ratio of partial pressure of arterial oxygen to fractional inspired oxygen concentration $\left(\mathrm{PaO}_{2} / \mathrm{FiO}_{2}\right)$ less than $300 \mathrm{mmHg}$ or oxygen saturation of $\leq 90 \%$ in room air associated with bilateral infiltrates on frontal chest radiograph in the absence of signs of circulatory overload. Herein, we present a 59-year-old male case with iatrogenic intraabdominal bleeding due to paracentesis who developed TRALI following fresh frozen plasma transfusion.
\end{abstract}

Key words: Blood transfusion, Acute Lung Injury, paracentesis.

A number of hospitalized patients need transfusion of blood products for various reasons. Therefore, it is essential for all healthcare professionals be aware of transfusion-related complications and their management. Transfusion-related acute lung injury (TRALI) is an important and potentially fatal complication, which is the leading cause of transfusion-related deaths and there are several case

\section{Özet}

Birçok hastanın çeşitli nedenlerle kan transfüzyonuna ihtiyacı olmaktadır. Transfüzyonla ilişkili akut akciğer hasarı (TRALI) hayati risk taşıyabilen önemli bir komplikasyon olup transfüzyonla ilişkili ölümlerin en sık nedenidir. TRALI bir tür akut non-kardiyojenik akciğer ödemi tablosudur. TRALI tanısı Ulusal Kalp-Akciğer ve Kan Enstitüsü Çalışma Gurubu (NHLBI) ya da Kanada Konsensus Toplantısı Kriterleri'ne göre konur. Tanı için akut hipoksi gelişimini gösteren parsiyel arteryel oksijen basıncının, solunan havanın fraksiyonel oksijen konsantrasyonuna oranının 300 mmHg'nın altında olması ya da oda havası solurken oksijen satürasyonunun <\%90 olması parametreleri ile akciğer grafisinde bilateral infiltrasyon varlığı ve volüm yüklenmesi bulgularının olmaması gereklidir. Burada, tanısal parasentez sonrası iyatrojenik intra-abdominal kanama gelişen ve taze donmuş plazma transfüzyonuna bağlı TRALI ortaya çıkan bir olgu sunulmuştur.

Anahtar Sözcükler: Kan transfüzyonu, Akut Akciğer Hasarı, parasentez.

reports published in the literature (1-3). It is usually under diagnosed due to various factors including unawareness among the clinicians (4). Transfusion-related acute lung injury can be defined as acute lung injury (ALI) with no other etiology developing during or within six hours of transfusion of blood products. It can be diagnosed according to the National Heart Lung and Blood Institute

'Department of Gastroenterology, Necmettin Erbakan University Meram Faculty of Medicine, Konya, Turkey

'Necmettin Erbakan Üniversitesi, Meram Tıp Fakültesi, Gastroenteroloji Anabilim Dalı, Konya

${ }^{2}$ Department of Internal Medicine, Necmettin Erbakan University $\quad{ }^{2}$ Necmettin Erbakan Üniversitesi, Meram Tıp Fakültesi, İç

Meram Faculty of Medicine, Konya, Turkey

Hastalıkları Anabilim Dalı, Konya

Submitted (Başvuru tarihi): 18.04.2016 Accepted (Kabul tarihi): 29.06.2016

Correspondence (iletişim): Mehmet Asıl, Department of Gastroenterology, Necmettin Erbakan University Meram

Faculty of Medicine, Konya, Turkey

e-mail:drmehmetasil@yahoo.com.tr 
(NHLBI) Working Group or The Canadian Consensus Conference criteria $(5,6)$. Diagnosis requires an acute onset of hypoxemia with a ratio of partial pressure of arterial oxygen to fractional inspired oxygen concentration $\left(\mathrm{PaO}_{2} / \mathrm{FiO}_{2}\right)$ less than $300 \mathrm{mmHg}$ or oxygen saturation of $\leqslant 90 \%$ in room air associated with bilateral infiltrates on frontal chest radiograph in the absence of signs of circulatory overload (pulmonary arterial occlusion pressure $\leqslant 18 \mathrm{mmHg}$ or a lack of clinical evidence of left atrial hypertension). The clinical presentation includes a sudden-onset respiratory failure with dyspnea, tachypnea, and ventilatory mechanical support is frequently needed. Herein, we present a 59-year-old male patient with iatrogenic intra-abdominal bleeding due to paracentesis who developed TRALI following fresh frozen plasma transfusion.

\section{CASE}

A 59-year-old male patient was admitted to our gastroenterology clinic for the complaint of diarrhea for one year. $\mathrm{He}$ underwent a mitral valve replacement operation with a metallic prosthetic valve 20 years ago and was on warfarin treatment since then. Physical examination was normal except the sound of metallic prosthetic heart valve on cardiac auscultation. Laboratory studies were unremarkable, except the presence of mild anemia on complete blood count (CBC) with hemoglobin $(\mathrm{Hb}): 10.2 \mathrm{~g} / \mathrm{dl}$ and hematocrit (Hct): 29.9 \%. Prothrombin time (PT) was prolonged $(27.7 \mathrm{sec})$ with an international normalized ratio (INR) of 2.5 due to warfarin usage. Abdominal ultrasound showed the presence of ascites and paracentesis was performed for diagnostic purposes. Ascites fluid was clear in gross appearance and samples were sent to laboratory for biochemical, cytological, and microbiological examinations. The $\mathrm{CBC}$ follow-up following paracentesis revealed a decrease in both $\mathrm{Hb}$ and $\mathrm{Hct}$ levels, and iatrogenic intra-abdominal bleeding was suspected. A second diagnostic paracentesis was performed which showed a fresh blood stained ascitic fluid, $\mathrm{Hb}$, and $\mathrm{Hct}$ concentrations in the ascitic fluid was measured as 6.1 $\mathrm{g} / \mathrm{dl}$ and $18 \%$ respectively. He was transferred to intensive care unit (ICU) for monitorization and close follow-up with the diagnosis of post-paracentesis iatrogenic intraabdominal bleeding. On immediate admission to the ICU, he was slightly tachycardic and hypotensive (pulse rate $110 / \mathrm{min}$, blood pressure: $95 / 60 \mathrm{mmHg}$ ). Physical examination findings were still unremarkable. Breathing was comfortable with a rate of $12 / \mathrm{min}$ and there were no sign of any respiratory distress. On auscultation, lungs were expanding equally and pulmonary sounds were normal. Laboratory studies revealed a fall in both blood $\mathrm{Hb}$ and Hct levels (Hb: $6.2 \mathrm{~g} / \mathrm{dl} \mathrm{Hct:} \mathrm{19.1 \% ),} \mathrm{and} \mathrm{PT} \mathrm{was} 18 \mathrm{sec}$ (INR: 2.5). Immediate resuscitative measures were taken and transfusion of two units of packed red blood cells (PRBCs), and two units of fresh frozen plasma (FFP) were initiated. Within the following 48 hours, a total of six units of PRBCs and six units of FFP were transfused with close monitoring of vital signs, central venous pressure (CVP), $\mathrm{Hb}, \mathrm{Hct}$, and PT values. Within one hour after the institution of the last unit of transfusion of FFP, the patient developed a sudden-onset respiratory distress with severe dyspnea and tachypnea (18/min). Tachycardia and hypotension also developed (pulse: 120/min, blood pressure: $85 / 65 \mathrm{mmHg}$ ). Bilateral fine crepitation were audible on auscultation of the lungs, and arterial blood gases showed the presence of hypoxia and hypercapnia $(\mathrm{pH}$ : 7.41, $\mathrm{PaO}_{2}: 65 \mathrm{mmHg}, \mathrm{pCO}_{2}: 54 \mathrm{mmHg}$ and $\mathrm{SO}_{2}$ : $75 \%)$. The patient was immediately intubated, and tracheal aspiration after intubation yielded a pinky edema fluid of moderate amount. Chest $\mathrm{X}$-ray showed diffuse bilateral coalescent opacities in the lungs consistent with pulmonary edema. There were no sign of circulatory volume overload and CVP was $5 \mathrm{mmH} 2 \mathrm{O}$. Transthoracic echocardiography showed that the prosthetic valve was functioning properly, right and left heart chambers were normal with no sign of heart failure or circulatory overload. Cardiac wall motion was assessed as normal without any sign of hypokinesia and ejection fraction was measured as $55 \%$. Thoracic computed tomography (CT) showed diffuse consolidation areas in both lungs (Figures 1 and 2). Pulmonary vasculatures were found to be normal in CT with no sign of pulmonary thromboembolism. Based upon clinical, laboratory and radiological criteria, TRALI was diagnosed. Transfusion was stopped immediately. Vasopressor treatment and intravenous (IV) fluid resuscitation were initiated to correct hypotension, and diuretics were avoided. The patient responded well to the treatment, and vasopressor treatment was discontinued within 24 hours. Mechanical ventilatory support was continued for seven days, hypoxemia and hypercapnia resolved, and the patient was extubated after a successful weaning period.

\section{DISCUSSION}

Transfusion-related acute lung injury is a form of acute non-cardiogenic pulmonary edema characterized by sudden-onset dyspnea, hypoxia, and bilateral edematous infiltrations on chest radiographs associated with transfu- 
sion of blood products. It is the most important transfusion-related complication associated with significant morbidity and mortality (1). The term TRALI was first proposed by Popovsky et al. (7) in 1983 who also published the first case series in 1985 (8). The exact pathophysiological mechanisms underlying TRALI have not been fully understood, yet. According to the widely accepted 'two-hit' hypothesis, the patient-related clinical factors such as infection, trauma, surgery, or massive transfusion result in the first hit with the activation of the pulmonary endothelium and the release of several cytokines and adhesion molecules. Polymorphonuclear leucocytes (PMNs) are primed and sequestrated on to the activated pulmonary endothelium. The second hit comes from the donor; after transfusion, these primed PMNs of the recipient interact with leukocyte antibodies or biological response modifiers of donor plasma (9). Several oxidases and proteases are released which in term induce endothelial damage, capillary leak and development of non-cardiogenic pulmonary edema with a protein rich edema fluid. Antibodies to both human leukocyte antigens (HLA class I and II) and human neutrophil antigens (HNAs) are the key factors in the pathogenesis of immune mediated TRALI (10).

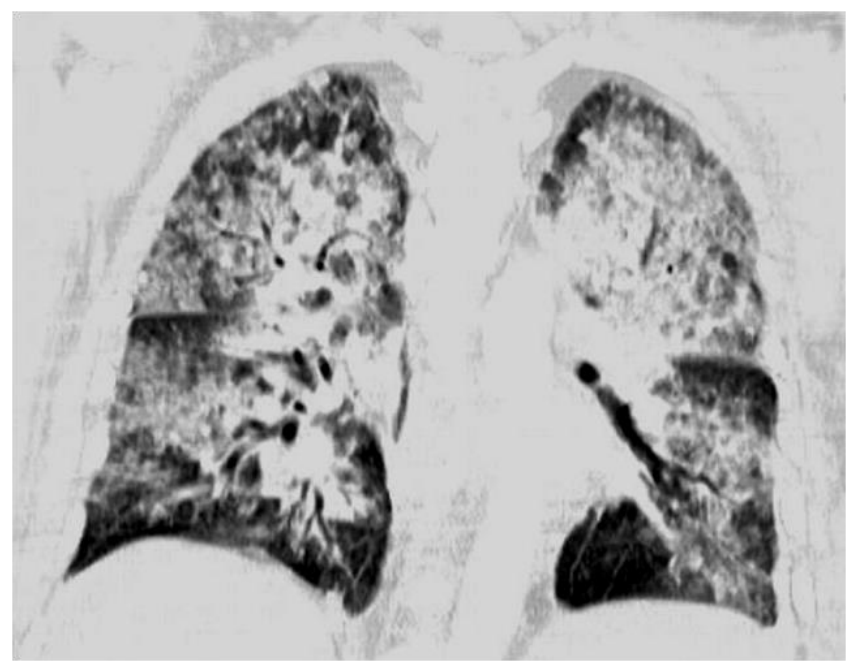

Figure 1: A thoracic computed tomography scan showing bilateral coalescent opacities in the lungs consistent with pulmonary edema

The differential diagnosis of acute lung injury following transfusion includes transfusion-associated circulatory overload (TACO), cardiogenic edema, allergic and anaphylactic transfusion reactions, and bacteremia/sepsis due to transfusion of bacterially contaminated blood products (11). Of these, TACO and cardiogenic pulmonary edema are of particular importance, as both are frequently encountered in hospitalized patients and in those admitted to the ICU. Treatment strategies of both conditions are also quite different from TRALI. Patients with TACO and cardiogenic pulmonary edema usually require diuretic treatment and fluid restriction, whereas such strategies should be avoided in patients with TRALI. In our case, there were no physical signs of volume overload or heart failure. Central venous pressure was normal and transthoracic echocardiography showed that the prosthetic valve was functioning properly, ejection fraction was measured as 55\%, and there were no sign of cardiac dysfunction.

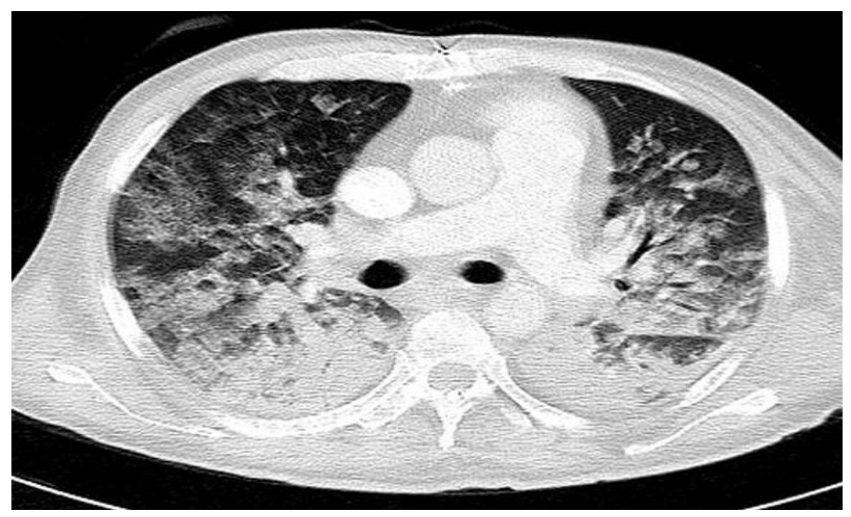

Figure 2: A thoracic computed tomography scan showing diffuse consolidation areas in both lungs

Treatment of TRALI is mainly supportive. Transfusion should be stopped immediately. Mild forms of TRALI can be treated with conservative measures and supplemental oxygen therapy; however, more severe forms require mechanical ventilation and ICU support. The preferential use of lower tidal volumes during mechanical ventilator support has been suggested. There is no therapeutic role for diuretics or corticosteroids (12). The majority of patients recover within 96 hours without any apparent sequelae; however, in certain patients, it may take a week or longer for the patient to stabilize. Approximately 5 to $10 \%$ of cases are fatal despite aggressive supportive care (13). Our patient also needed mechanical ventilatory support for one week. Although vasopressor treatment and IV fluid resuscitation were initiated at the beginning to correct hypotension, treatment was discontinued within 24 hours.

The only proved strategy to prevent TRALI-related deaths is through mitigation strategies. The incidence of TRALI has decreased significantly with preferential use of plasma from male donors or female donors without a history of pregnancy (14). The preferential use of solvent detergent treated pooled plasma is also another preventive strategy (15).

In conclusion, TRALI is the most important transfusionrelated complication and is the leading cause of transfusion-related deaths. We believe that all healthcare pro- 
fessionals must be aware of the diagnosis and management of TRALI as well as other transfusion-related complications.

\section{CONFLICTS OF INTEREST}

None declared.

\section{AUTHOR CONTRIBUTIONS}

Concept - M.A., R.D., M.B., H.A., H.P., A.D.; Planning and Design - M.A., R.D., M.B., H.A., H.P., A.D.; Supervision - M.A., R.D., M.B., H.A., H.P., A.D.; Funding - A.D., H.A., H.P.; Materials - R.D., M.A.; Data Collection and/or Processing - M.A., R.D., M.B.; Analysis and/or Interpretation - M.A., R.D., M.B., H.P.; Literature Review R.D., M.B., H.A.; Writing - M.A., R.D.; Critical Review M.A., R.D., M.B., H.A., H.P., A.D.

\section{YAZAR KATKILARI}

Fikir - M.A., R.D., M.B., H.A., H.P., A.D.; Tasarım ve Dizayn - M.A., R.D., M.B., H.A., H.P., A.D.; Denetleme M.A., R.D., M.B., H.A., H.P., A.D.; Kaynaklar - A.D., H.A., H.P.; Malzemeler - R.D., M.A.; Veri Toplama ve/veya İşleme - M.A., R.D., M.B.; Analiz ve/veya Yorum - M.A., R.D., M.B., H.P.; Literatür Taraması - R.D., M.B., H.A.; Yazıyı Yazan - M.A., R.D.; Eleştirel İnceleme - M.A., R.D., M.B., H.A., H.P., A.D.

\section{REFERENCES}

1. American Association of Blood Banks (AABB). TRALI Risk Mitigation for Plasma and Whole Blood for Allogeneic Transfusion. Association Bulletin \#14-02, January 29, 2014.

2. Akyol PY, Unlüer EE, Elibol P, Karagöz A, Topal FE. A rare cause of dyspnea in emergency medicine: transfusion-related acute lung injury. Am J Emerg Med 2013; 31:1626.e1-2. [CrossRef]

3. Bitargil M, Arslan C, Başbuğ HS, Göçer H, Günerhan Y, Bekov YY. Transfusion-related acute lung injury following coronary artery bypass graft surgery. Perfusion 2015; 30:626-8. [CrossRef]

4. Wallis JP. Transfusion-related acute lung injury (TRALI)-under-diagnosed and under-reported. Br J Anaesth 2003; 90:573-6. [CrossRef]
5. Toy P, Popovsky MA, Abraham E, Ambruso DR, Holness LG, Kopko PM, et al. Transfusion-related acute lung injury: definition and review. Crit Care Med 2005; 33:721-6. [CrossRef]

6. Kleinman S, Caulfield T, Chan P, Davenport R, McFarland J, McPhedran S, et al. Toward an understanding of transfusion-related acute lung injury: statement of a consensus panel. Transfusion 2004; 44:1774-89. [CrossRef]

7. Popovsky MA, Abel MD, Moore SB. Transfusion-related acute lung injury associated with passive transfer of antileukocyte antibodies. Am Rev Respir Dis 1983; 128:185-9.

8. Popovsky MA, Moore SB. Diagnostic and pathogenetic considerations in transfusion-related acute lung injury. Transfusion 1985; 25:573-7. [CrossRef]

9. Silliman CC. The two-event model of transfusion-related acute lung injury. Crit Care Med 2006; 34 (5 Suppl):S124-31. [CrossRef]

10. Reil A, Keller-Stanislawski B, Gunay S, Bux J. Specificities of leucocyte alloantibodies in transfusion-related acute lung injury and results of leucocyte antibody screening of blood donors. Vox Sang 2008; 95:313-7. [CrossRef]

11. Kim J, $\mathrm{Na} \mathrm{S}$. Transfusion-related acute lung injury; clinical perspectives. Korean J Anesthesiol 2015; 68:101-5. [CrossRef]

12. Goldberg AD, Kor DJ. State of the art management of transfusion-related acute lung injury (TRALI). Curr Pharm Des 2012; 18:3273-84. [CrossRef]

13. Moore SB. Transfusion-related acute lung injury (TRALI): clinical presentation, treatment, and prognosis. Crit Care Med 2006; 34(5 Suppl):S1 14-7. [CrossRef]

14. Toy P, Gajic O, Bacchetti P, Looney MR, Gropper MA, Hubmayr $R$, et al. Transfusion-related acute lung injury: incidence and risk factors. Blood 2012; 119:1757-67. [CrossRef]

15. Ozier $Y$, Muller JY, Mertes PM, Renaudier P, Aguilon $P$, Canivet $\mathrm{N}$, et al. Transfusion-related acute lung injury: reports to the French Hemovigilance Network 2007 through 2008. Transfusion 2011; 51:2102-10. [CrossRef] 